\title{
䛾演
}

\section{三攴种經二 就 テ}

醫學博士 進 藤 篤一

此ノ盛大ナル九州䓝科醫學會二於テ淺學不才八私ガ三叉神經ニ就テ特別講演アナスノ機會

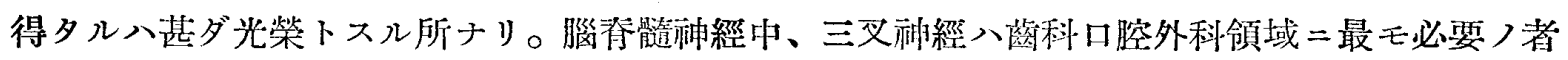
ナレバ、本神經二對スル諸君ノ知識つ豐富ナルベキヨ信ズ。故二私ノ講演入全ク蛇足ノ謗アラ

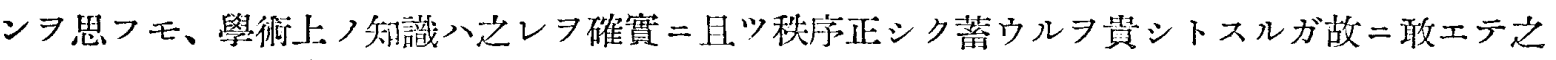
ヨ試ムル事ト七リ。

$(\rightarrow$ 三叉神經ノ意義

諸君御承知ノ如ク、三叉神經八第五腦神經ニシテ、ワロル氏橋ノ外側部ニ於テ發ス。其ノ根

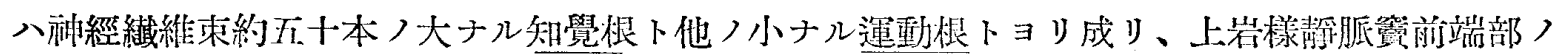

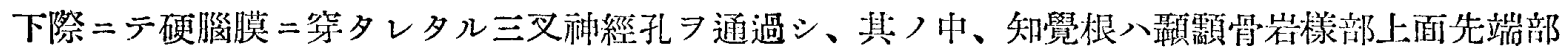

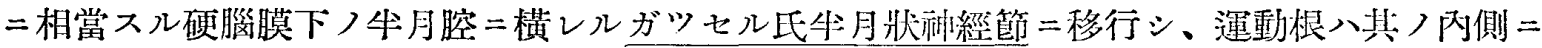
沿ヒテ進ム。次デガツセル氏神經節つ前凸彎緣ョリ大ナル三枝、即チ第一眼神經、第二上顎种 經、第三下顎神經ヨ生ジ、運動根入勗嚼神經トシテ下顎神經ニ沿ヒテ下ル。

本來胎生學的二八三叉神經ハ後腦部腹側ヨリ發生シ、第一腑弓誘導體タル下頡、上顎及ビ上 顎ノ上方二分布スベク定メラレシ知覺神經ニシテ、勗畄筋ノ發生モ亦コノ部ナルラ以テ之レニ 運動神經加ハリシナリ。

叉三叉神經知覺根ノ起始細胞ハ之レラガツセル氏神經節二永ムベキナレド、其ノ中樞根ノ停

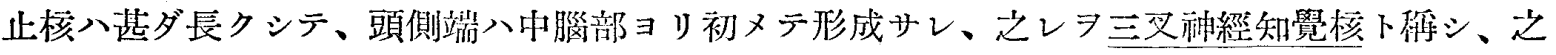

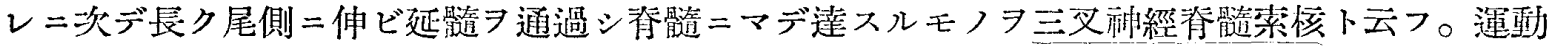

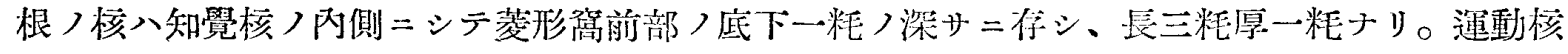
ノ神經ハ多極性ニシテ色素顆粒ヨ含ミ、直徑 60 -70「ミクロン」位ナリ。

(二) 第一枝 眼 齐 經

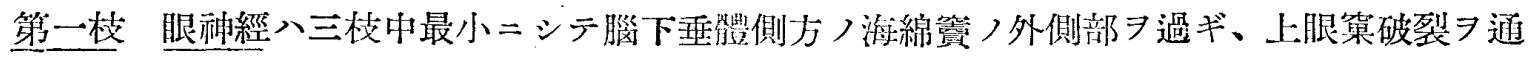

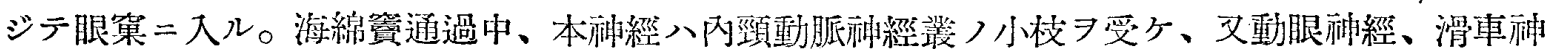

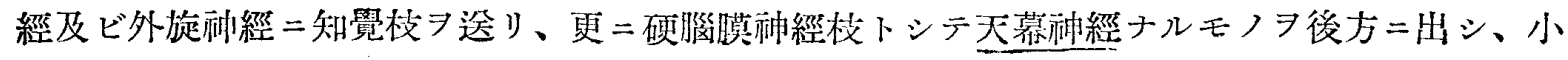




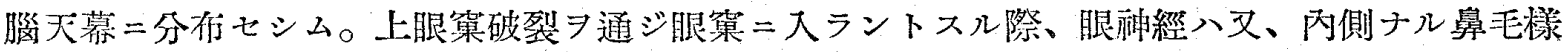
搹經、中央ナル前頭神經、外側ナル涙神經二三分ス。

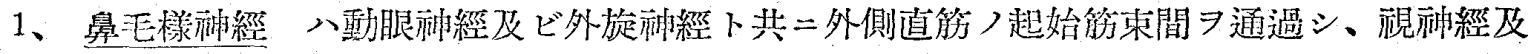
ビ上直筋つ間ヨ前內側方 $=$ 進ミ、眼笨內側壁二近キ、下滑車神經及ビ前節骨神經ノ二終枝二分

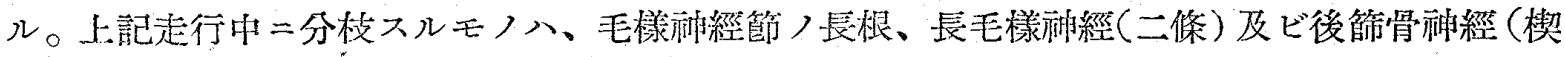
爿口蓋袖經節 眼案枝下共二後穊骨孔二大ル神經）等ナリ。

下滑車种經入上科筋ノ下二位シ、滑車ノ下方ニテ上及ビ下眼瞼枝トナリ、前者入上滑車神經

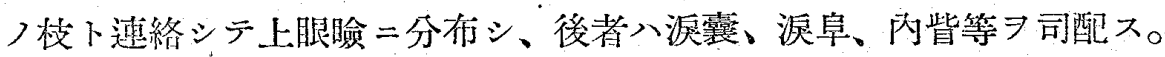

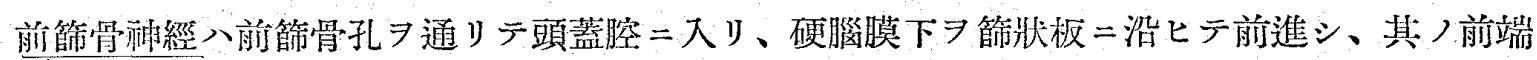
ノ大孔通過シテ鼻腔ニ下リ、前鼻枝トシテ鼻腔前部)粘膜二分仇スルモ（队鼻外側枝及ビ 內鼻內側枝）下外鼻皮膚二分布スルモ（外鼻枝）下二分ル。

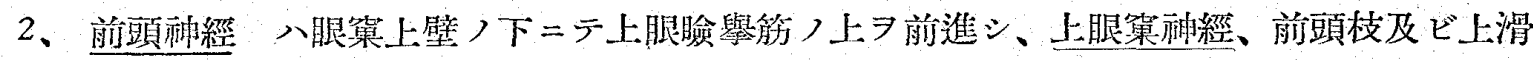

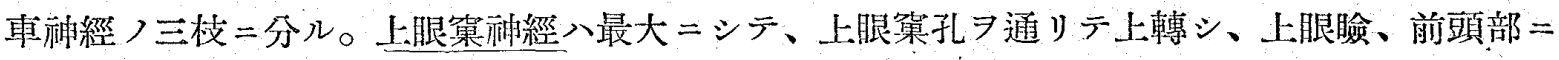

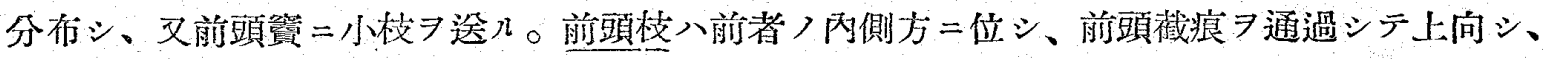
前頭部二至ル。上滑車神經ハ最小ナリ。之レハ滑車ノ上ヨ過ギ內㫮ノ上方二出デ上下ノ二枝卜 ナリテ分布ス。

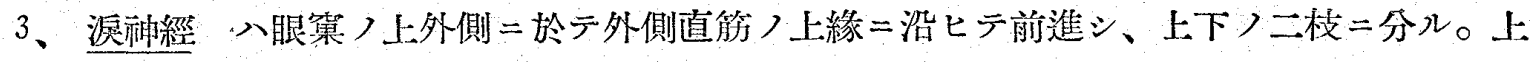

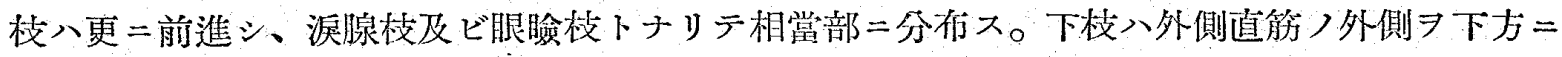
彎曲シ、顴骨种經吻合枝トシテ顴骨神經ノ枝に連絡シ、此つ吻合彎曲ヨリ涙腺二向七小枝ヨ放 \%。

(三) 第二枝 上顎 种䌈

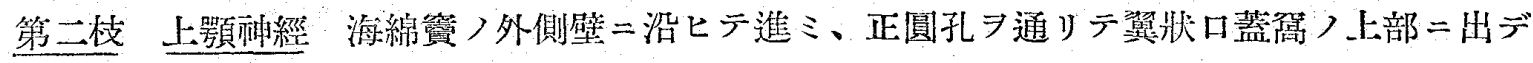

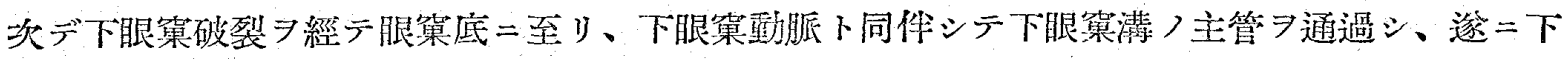

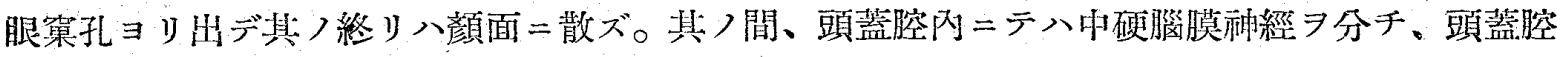

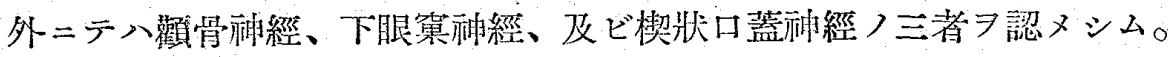

中硬腦膜种經入中硬腦膜動脈〉分布區域二配布セラル。

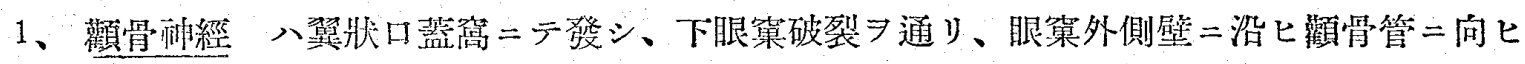

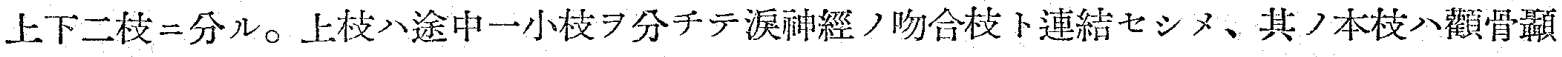

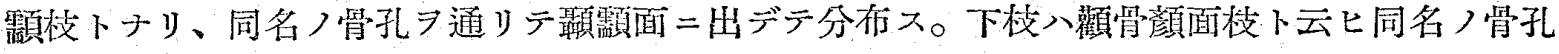
ヨ通リ、鹳骨部二配布ズ。

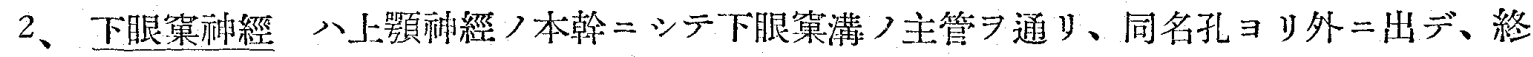

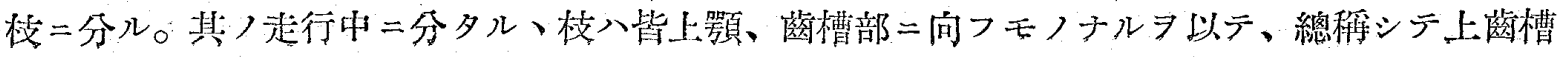


种經下呼バレ、更二後、中、前〉三種二分タル。

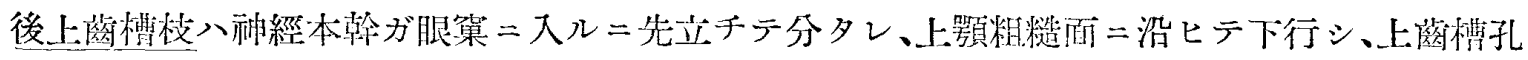

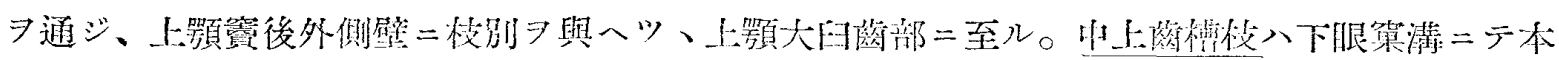

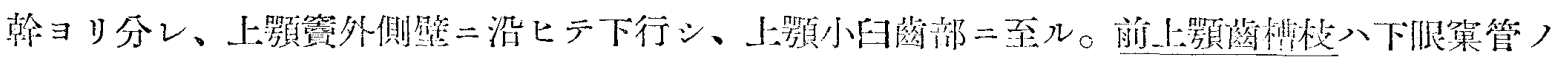
前端部ニテ本翰ヨリ發シ、上顎寶前壁ニ沿ヘル小管內

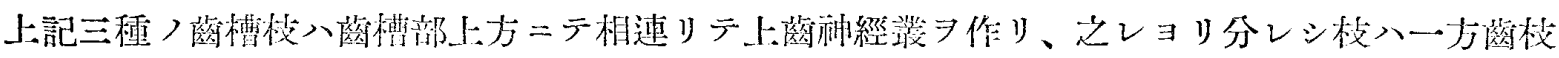

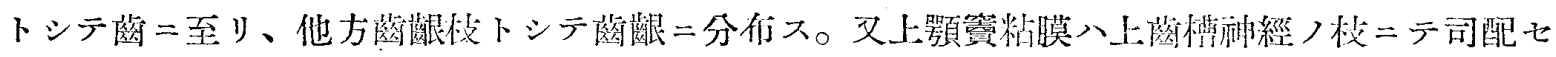

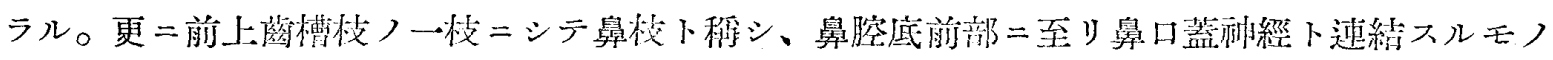
アリ。

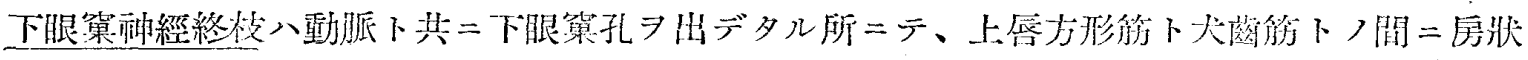

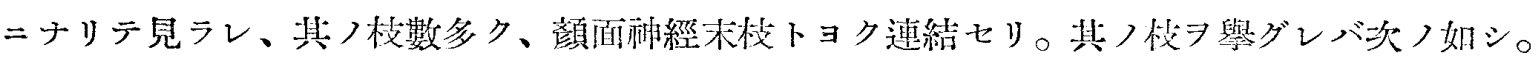

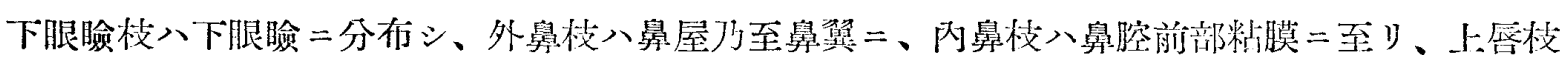
八上唇二分布ス。

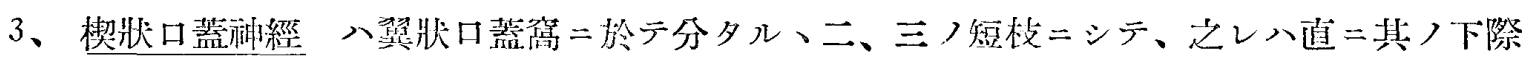

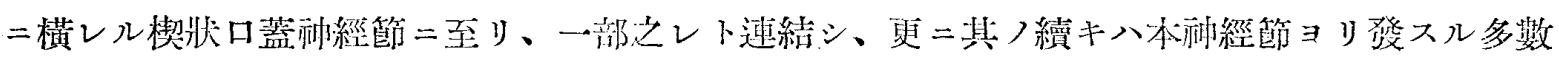

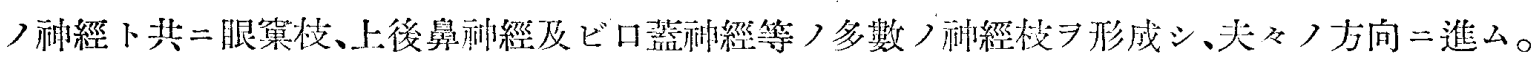

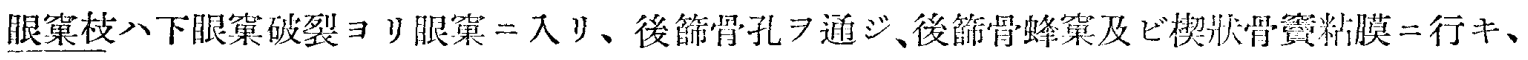
又視神經鞘ニモ小枝习與フ。

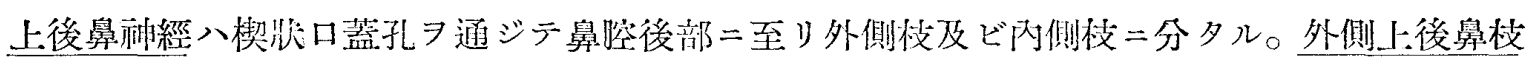
八咽頭上部、耳喇叭管、上及ビ币鼻甲介、上鼻道等)糊膜二分布大。内側上後鼻枝八鼻中隔後

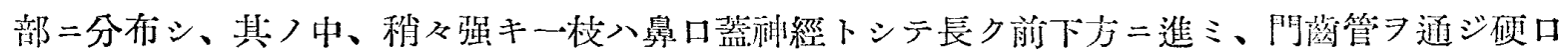

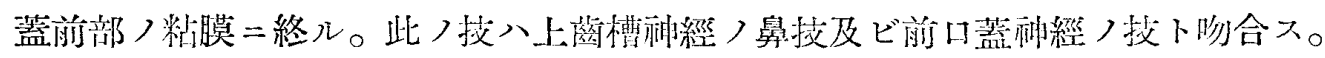

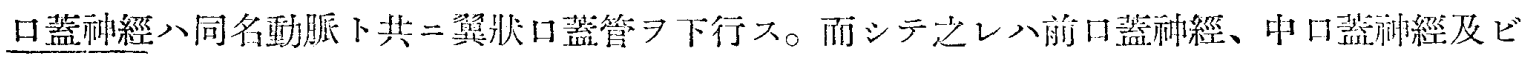

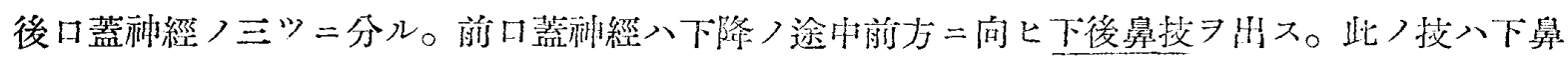

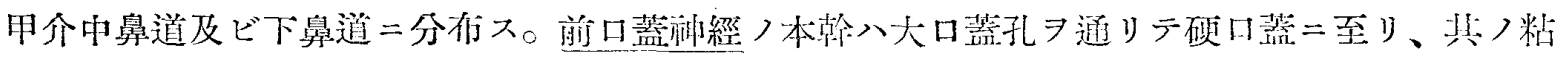

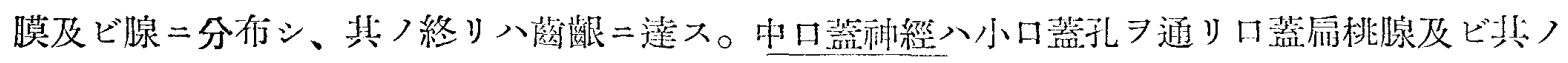

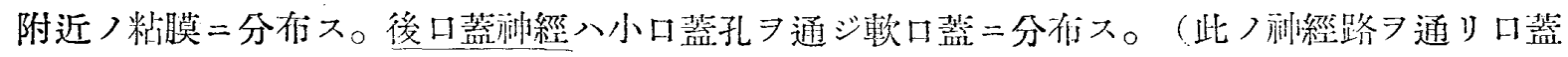

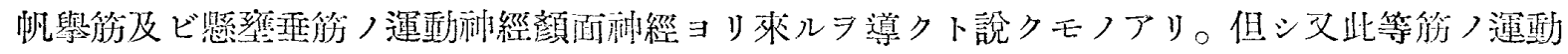
神經入咽頭神經览ヨリ來ルトスルモノアリ)。

(四) 第三枝 下顎 神 經

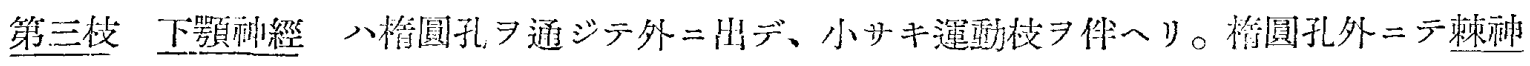

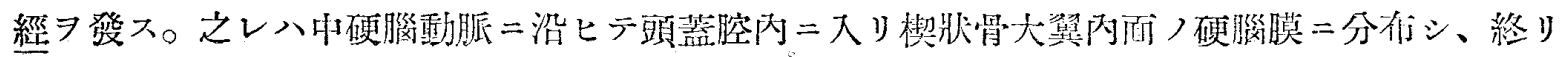




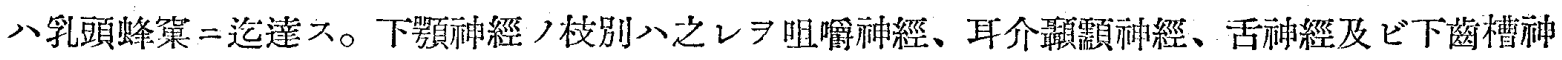
經ノ四ツニ分チ得。

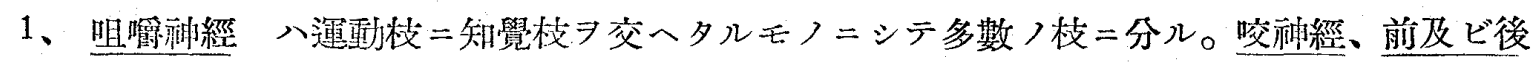

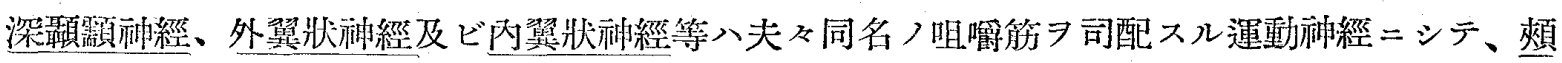

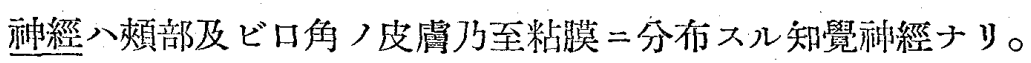

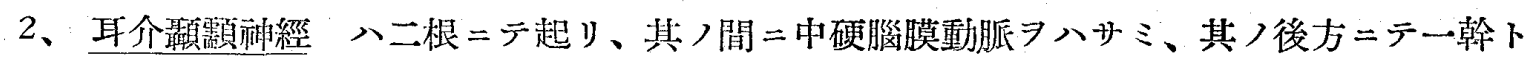

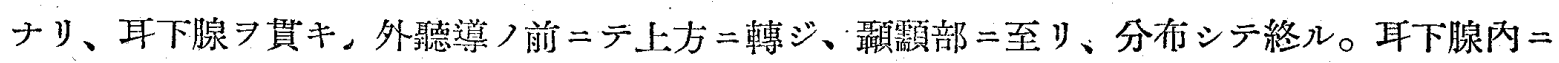
テ顔面神經ノ枝下吻合ス。其ノ枝別八、關節枝、耳下腺枝、外聽導神經、前耳介神經及ビ淺瓄 䫚枝ニシテ、夫ょ其ノ名ノ示ス所二分布ス。

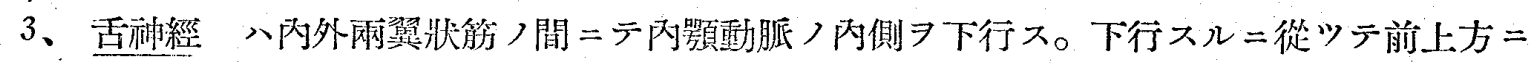

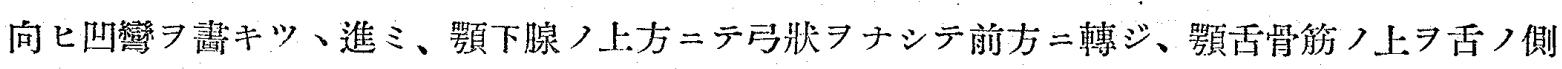
緣二至儿。其つ際、神經入顎下腺管ノ下外側二接觸シツ、舌骨舌管ノ外側二位七リ。舌渱經， 根部二近キ所ニデハ、顏面神經ヨリ發七ル鼔索神經ガ後上方ョリ來リテ之レニ合スルラ認ム。

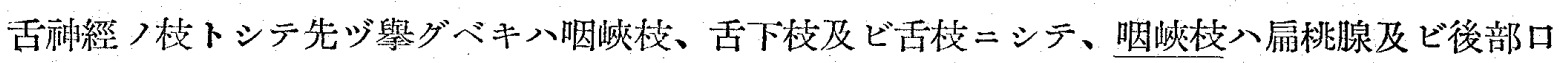
腔粘膜 $=$ 、舌下枝八口腔底粘膜及ビ舌下腺二、舌枝八舌〉前三分つ二つ舌粘膜、乳頭等二分布 주

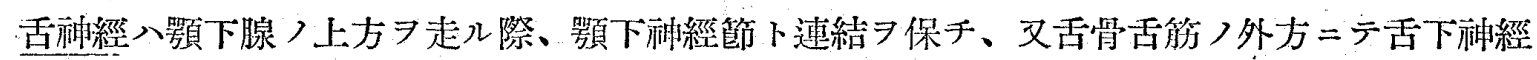
ノ枝下吻合ス。

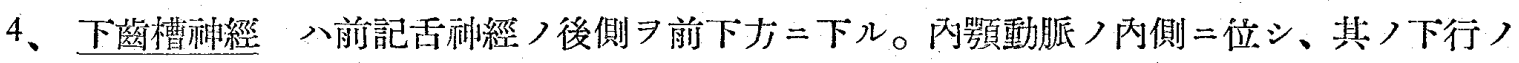

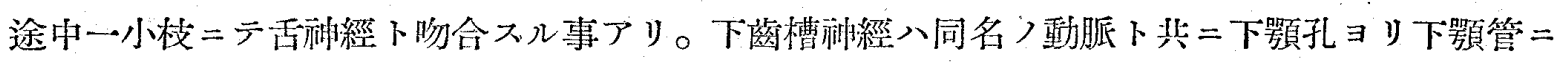
入ル。而シテ其ノ先端入本管ノ末端マデ澾スルモノアルト同時二、叉途中分レテ願孔ヨリ願神

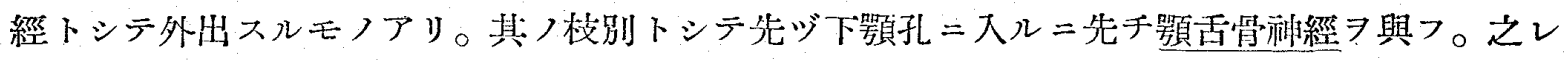

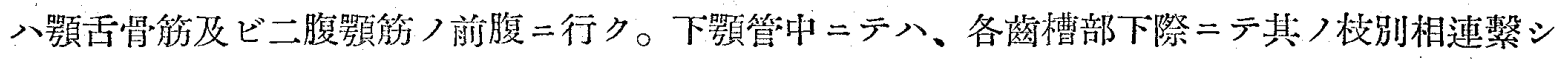

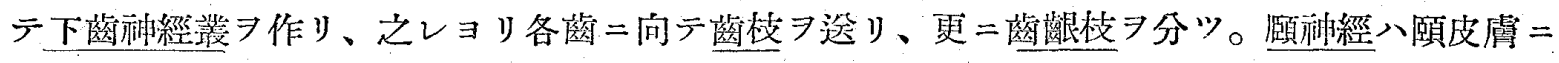
行ク順枝及ビ下唇二分布スル下唇枝二分レ、顏面神經ノ末枝ト良ク連結セリ。

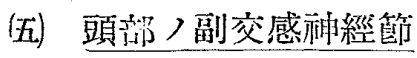

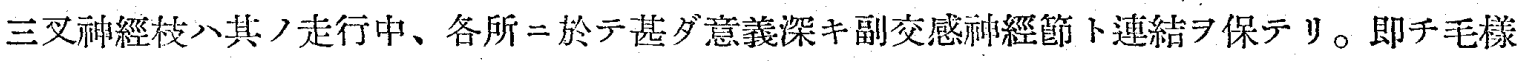
神經節、楔状口蓝神經節、耳神經節、及ビ頢下神經節ノ四者之レニシテ、以下之等ヨ說明スべ シ。

1、毛栐神經節 八視神經ノ外側 $=テ$ 、之レト外側直笳トノ間ナル脂肪組織中二横ハリ、屚 本不正長方形

本神經蓈二進入スル根二三種アリ。第一、運動根(短根)八動眼神經下枝ヨリ來リ、第二、知 


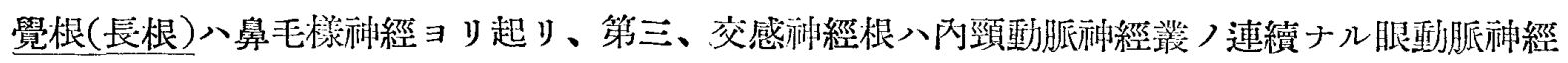
畒ヨリ與へラル。

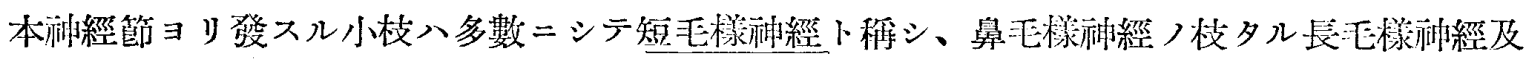

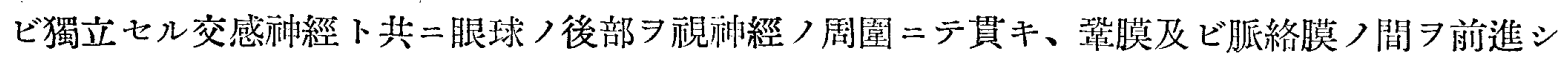

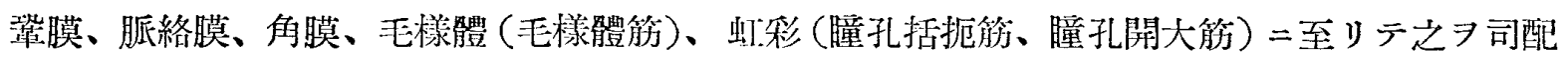
ス。

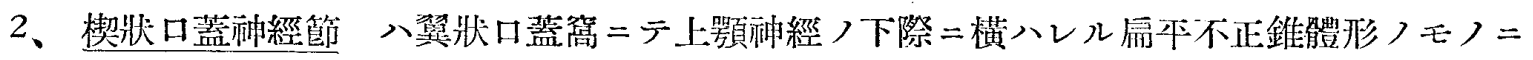
シテ、其ノ大斗八毛样神經節ヨリニ一三倍大ナリ。

本神經節ニ入ル根二三種アリ。第一、鋈動根入顏面神經ヨリ分岐セル大淺岩樣神經ニシテ、

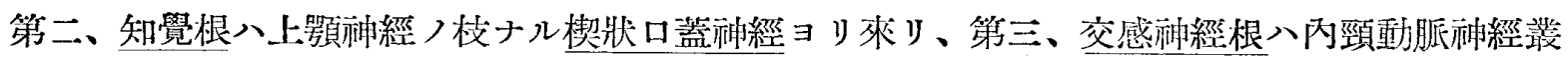
ヨリ分レ出デタル深岩樣神經ナリ。而シテ大淺岩樣神經卜深岩樣补經卜八相伴ヒテ琵狀管內 後方ヨリ前方二通過シ、グイデイ氏翼狀管神經卜一括命名セラレテ市經節後端二進大ス。

本神經節ヨリ發スル㖣經八以前与顎神經ノ佟下ニテ記述セシ眼案枝、」後鼻枝及ビ口蓝神經 ナレバ、再ビ茲ニ之レヨ說カズ。參照スベシ。

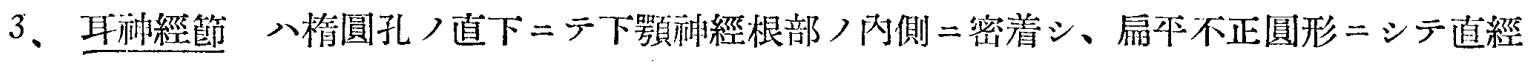
三一四粍ナリ。

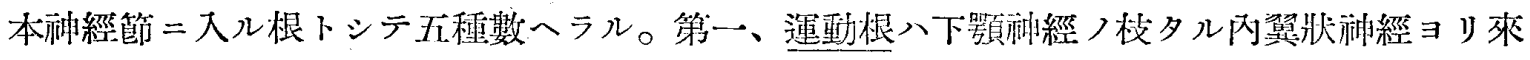

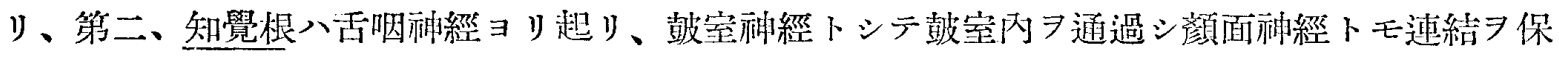

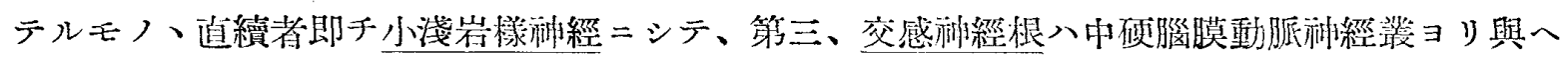

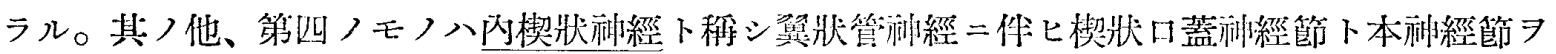

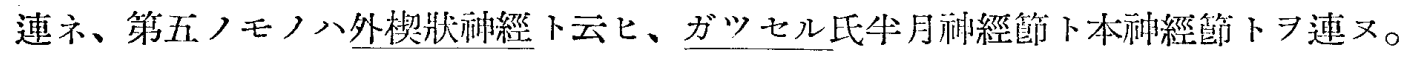

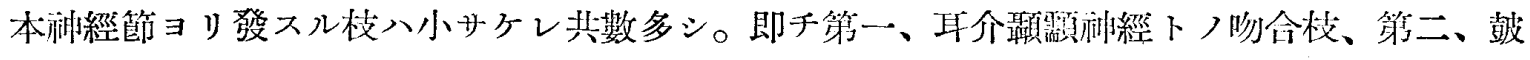

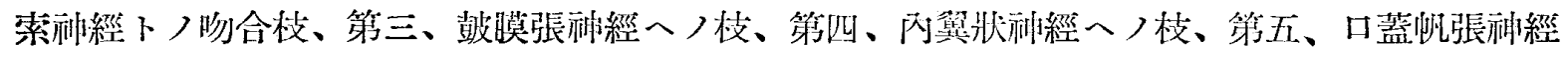
へノ枝、第六、頓种經へノ伎、第七、棘悚經へノ枝等之レナリ。

4、顎下神經節 八顎下腺ノ上方、吉神經ノ下ニ橫レル不正形ノ神經節ニシテ直徑三一三・ 五籷位ナリ。

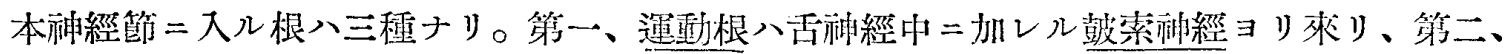
知覺根八舌神經ヨリ分レ、第三、交感神經根入外顎動脈神經筷ヨリ與へラル。而シテ第一及ビ 第二兩根八相合シ、後交通枝ノ名 $コ$ 以テ舌神經ヨリ本神經節ニ入ル。

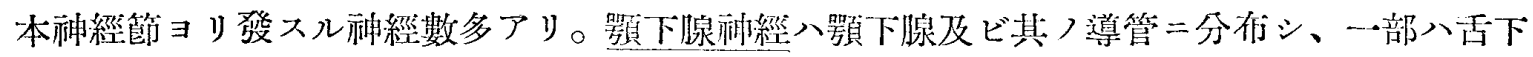

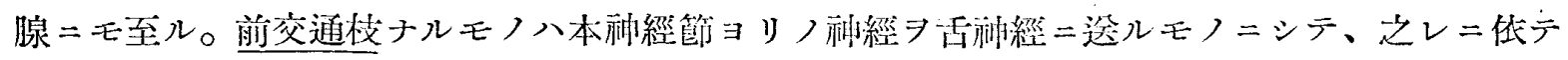
次二舌下神經 シ介シテ神經八舌下腺ニ揆ラル。又舌下神經卜連ルモノアリ。 


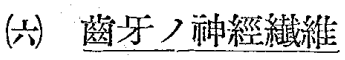

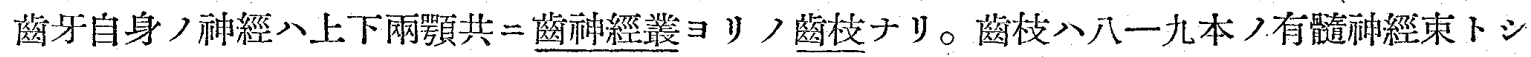

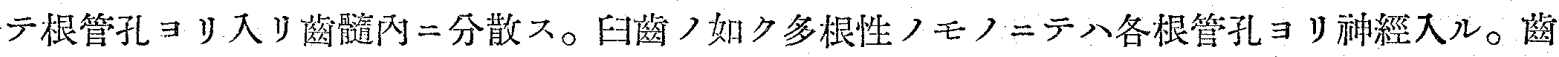

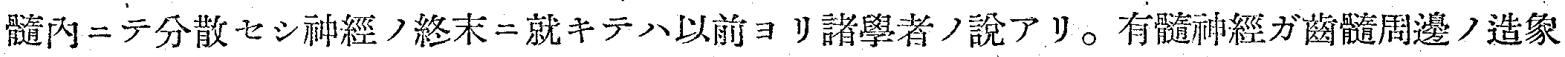

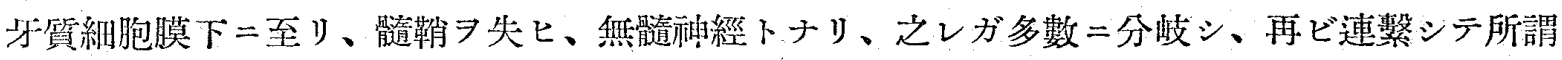
シシュカウ氏神經丵ヨ形成スル事八、皆學者〉認ムル所ニシテ、隹易二檢出七ラル。難問題

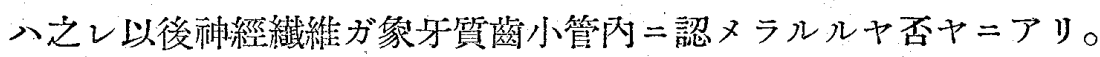

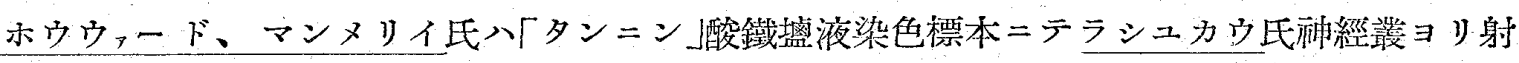

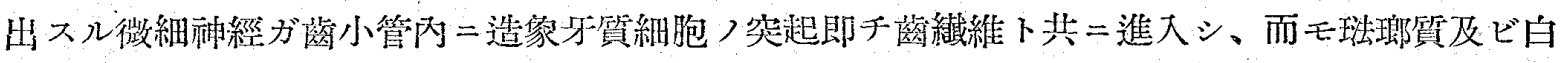

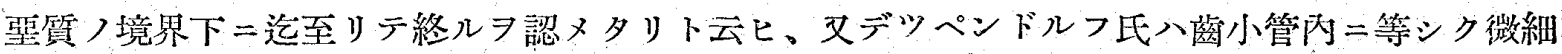
神經纎維 $フ$ 染出シテ供覽七リ。

其ノ後マンメリ一氏ノ研究ハ上記ヨリ稍タ異リテ進ミタル所見ヨ得タリ。有髓神經繊維入造

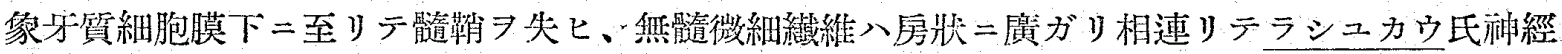

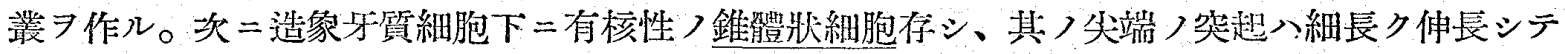

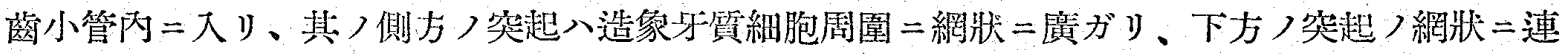

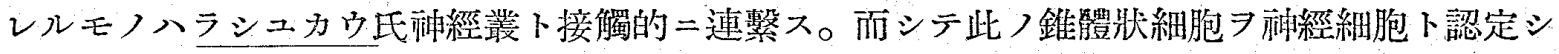

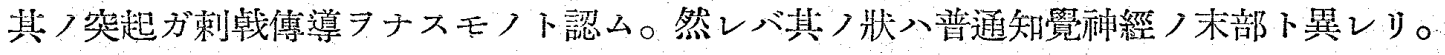

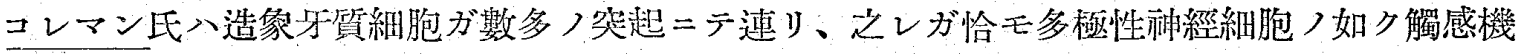

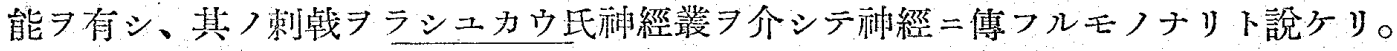

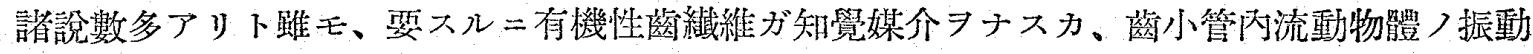

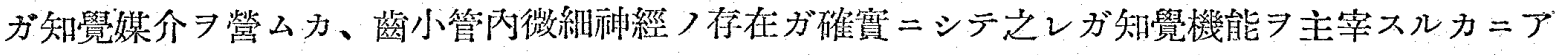

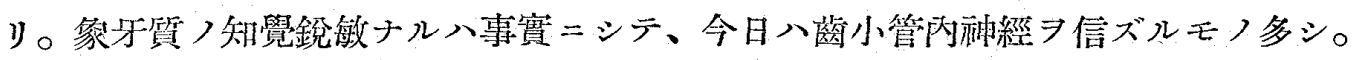

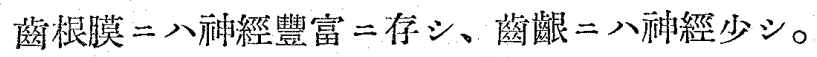

(七) 三叉种經ノ生㻎的意義、知覺枝及ビ運動枝

以上三文种經ノ解剖學的事實八、多年ノ經驗ニヨリ、少クトモ一度八私ノ眼二映ジ、叉手

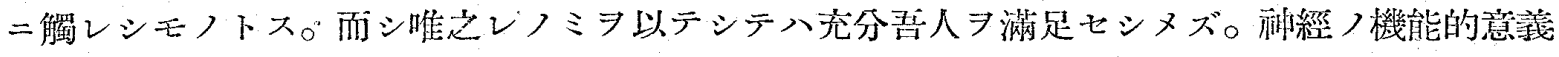

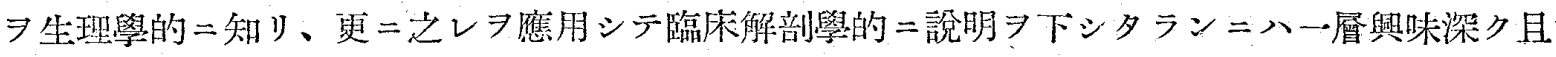
ツ有意義ノモノトナラン。

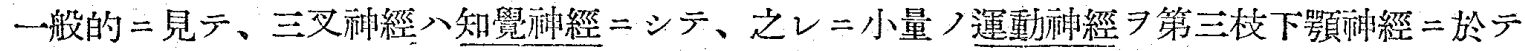
加味セルモノナル事八風知ノ事實ナ゙リサレドえレノミニテ充分ナラズ。三叉部經中二八又交

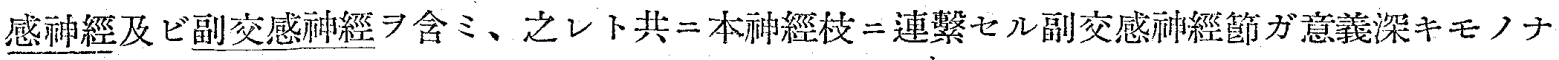

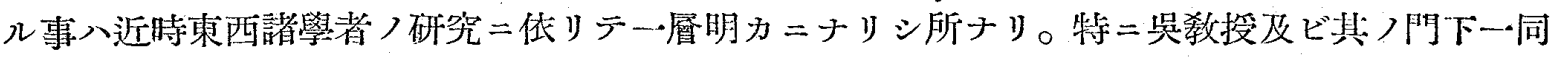


之レニ關スル研究成緽入选ダ見事ニシテ、此ノ領域ノ知見 7 開發七シモノ頗ル多シ。

三叉神經ノ知覺範園ブ一括スレバ次ノ如シ。

第一枝、眼神經)司配地。前頭部、上腿瞼、內皆及ビ鼻背等ノ皮膚、上眼瞼結膜、涙腺、眼

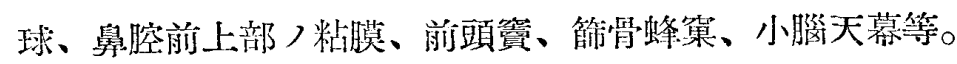

第二枝、上顎神經，司配地。下眼瞼ノ皮膚及ビ結膜、鼻屋及ビ鼻翼、上唇、煩上部、外㫮、

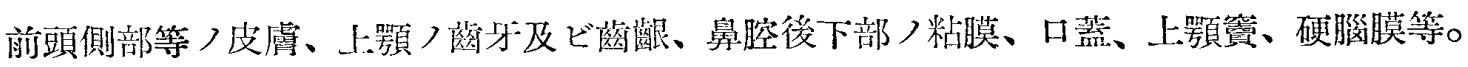

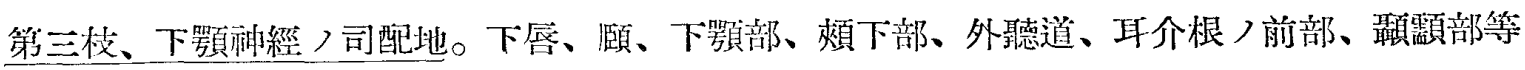

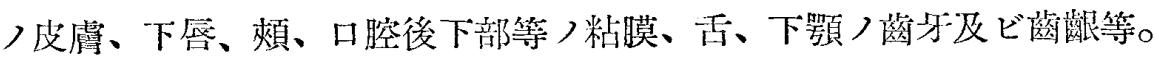

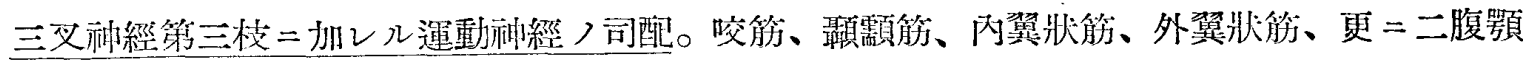

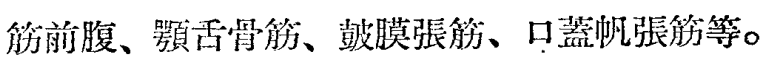

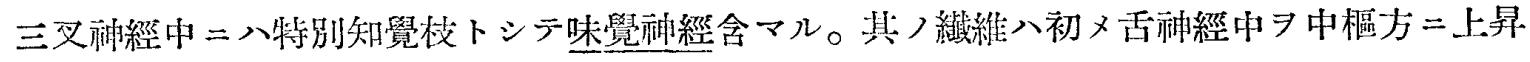

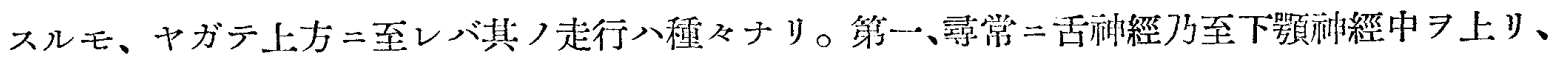

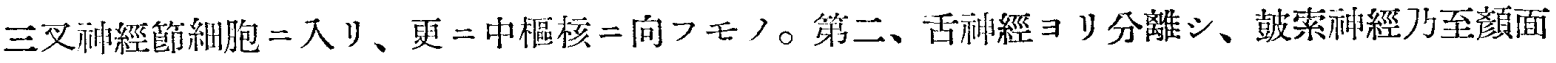

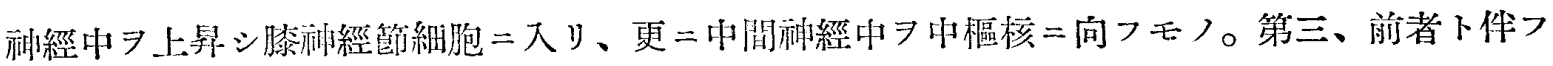

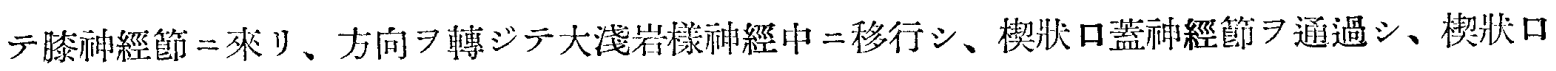
蓋神經、上顎种經中ヨ通リ、牛月神經笁細胞ニ入リ、更二中樞核二向フモノ。以上ノ外、舌後

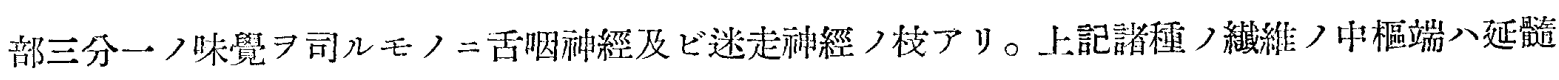
ノ孤素ナル中樞核二䌏ル。

(八) 三叉齐經，副交感种經及ビ交感神經

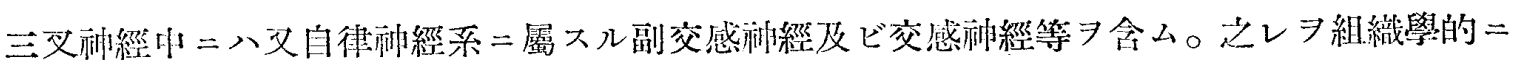

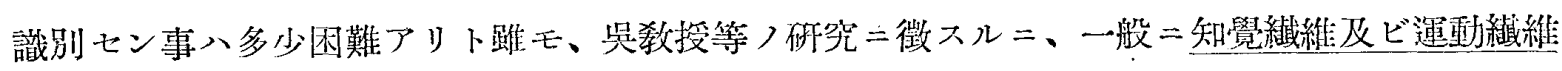

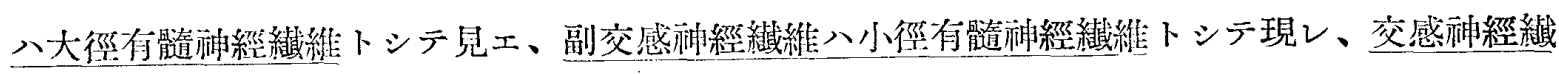

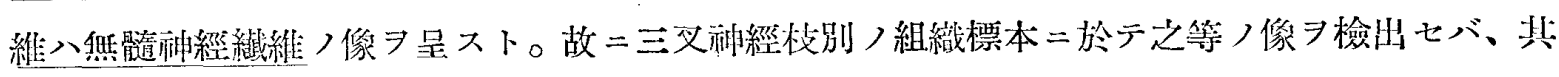
ノ神經つ配布フ知ルノ便宜 得ベシ。

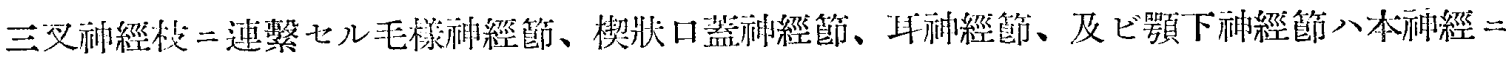

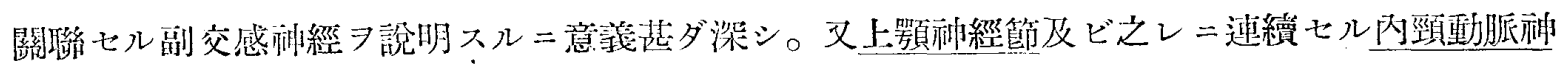

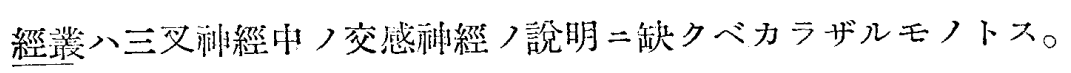

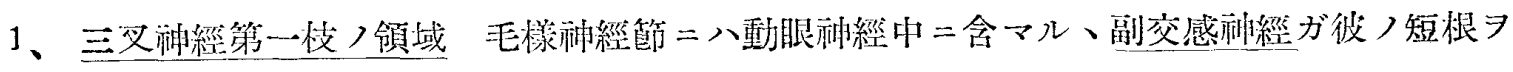

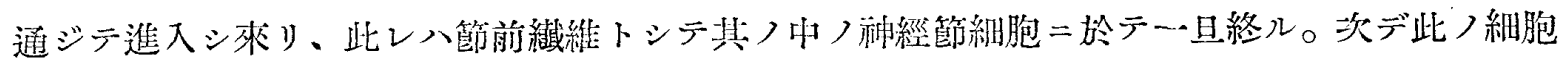

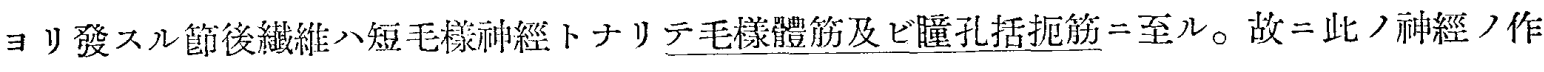

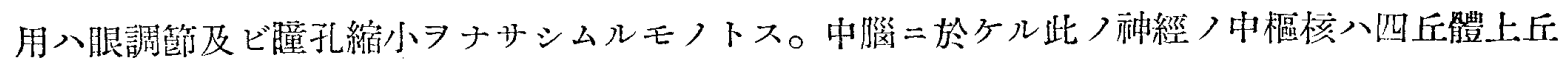

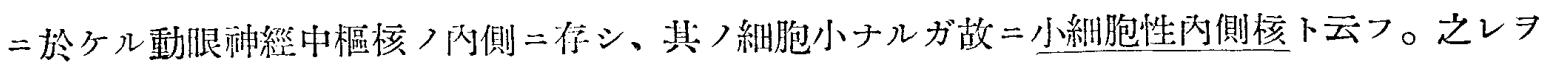




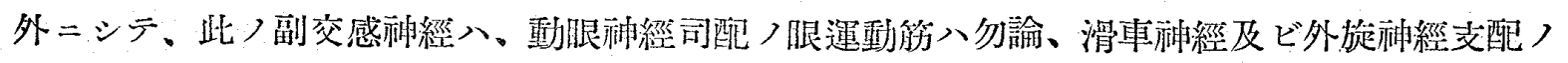
眼運動筋ニモ分布シ、其ノ榮養神經トシテ作用スルラ認ム。

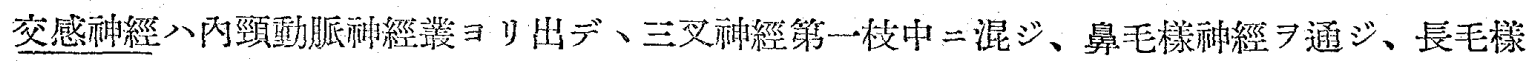
神經トシテ直接眼球二入ルモノアルト基二、文毛㨾神經節シ通過シテ眼球ニ入ルモノアリ。之

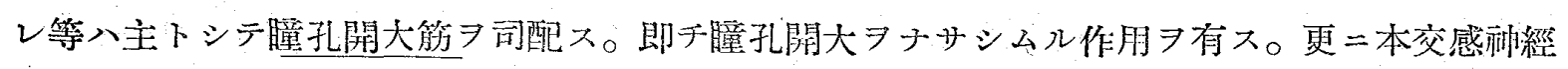

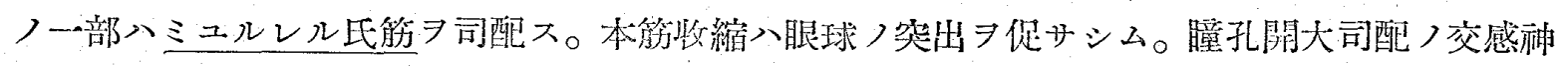

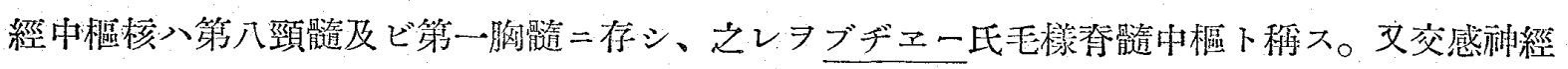

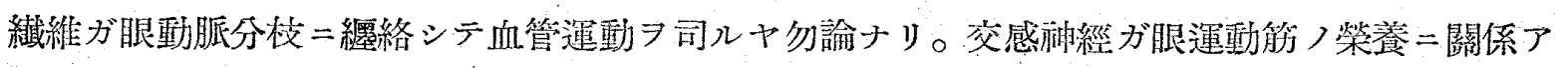
ルモ事實ナリ。

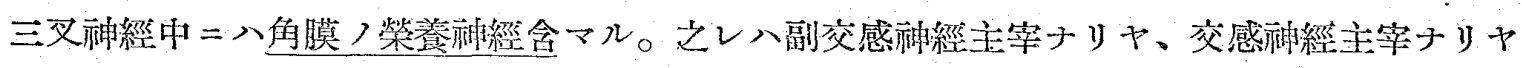

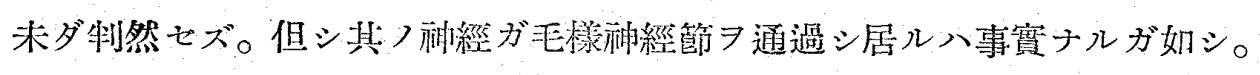

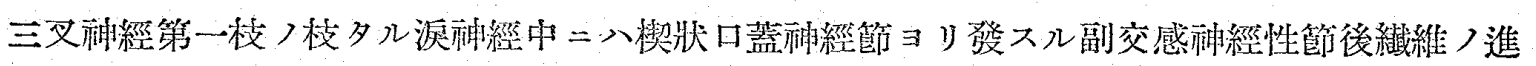

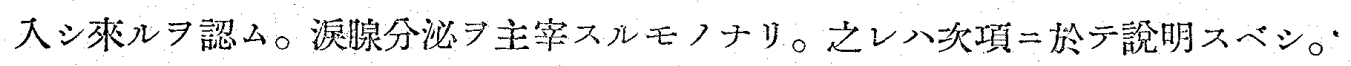

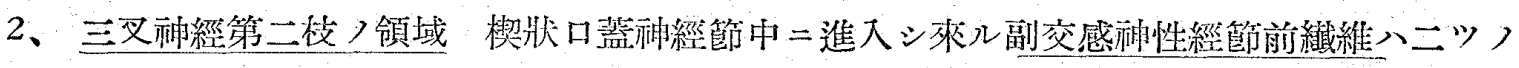

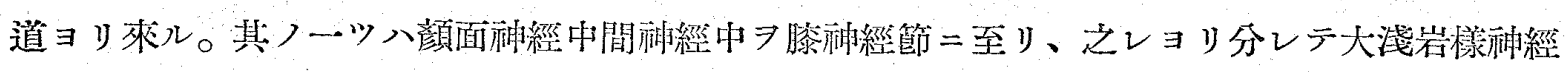

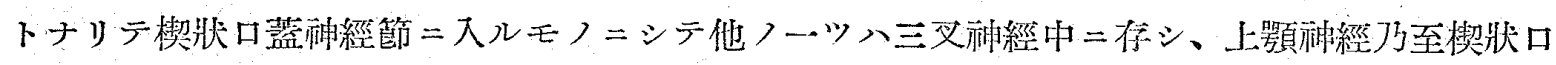

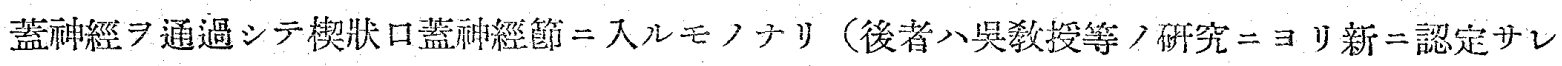
シモノトス)。此ノ副交感神經ノ中樞核八、大多極性神經細胞群ヨリ成レル顏面神經核ノ傍二存 スルモノニシテ・神經細胞小サク、之レヨ湜分泌卜稱ス。

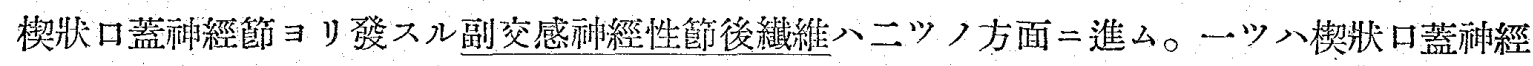

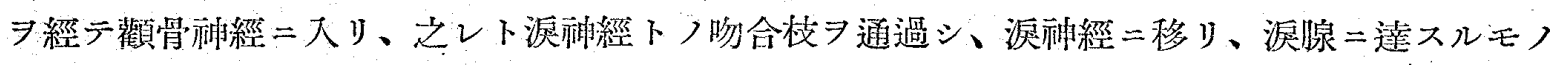

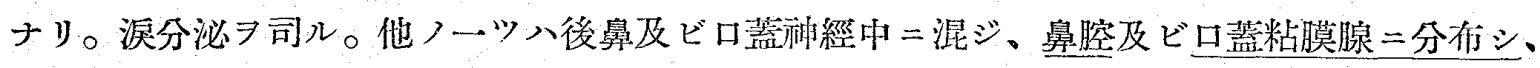

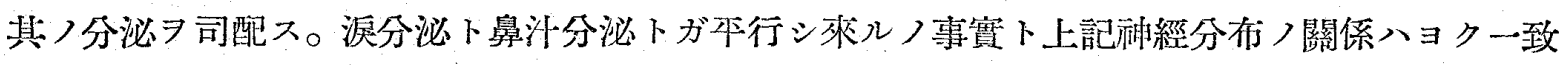
セリ。

此ノ領域ノ交感神經习觀察スルニ先ヅ內頸動脈神經装ヨリ分レ、深岩樣神經トシテ楔狀口葢

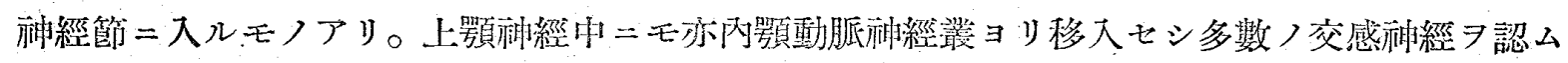

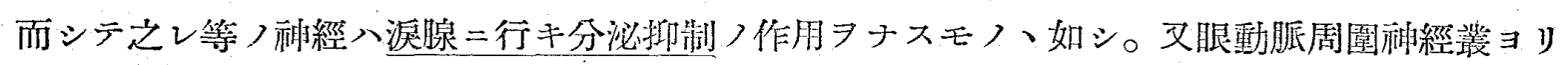

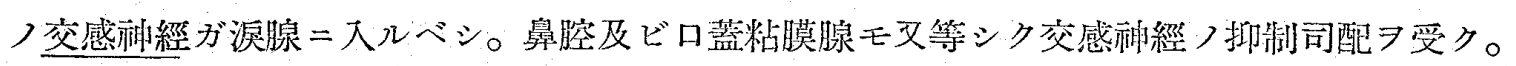

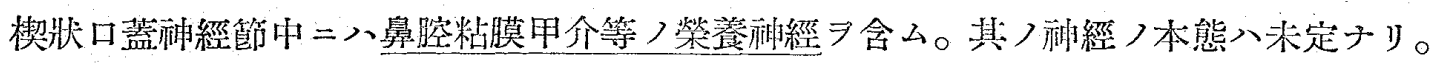

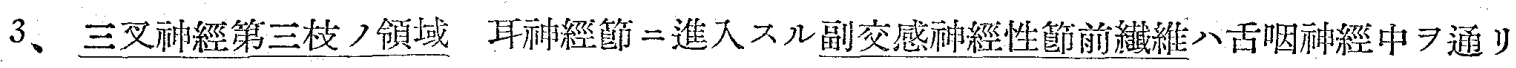

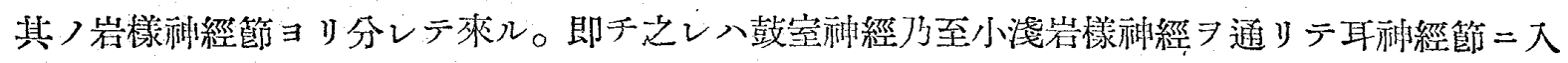

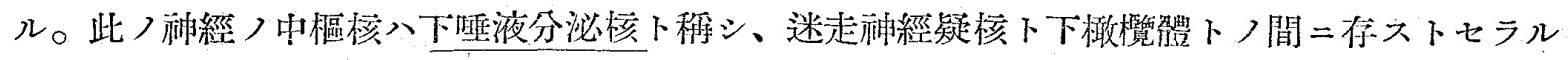




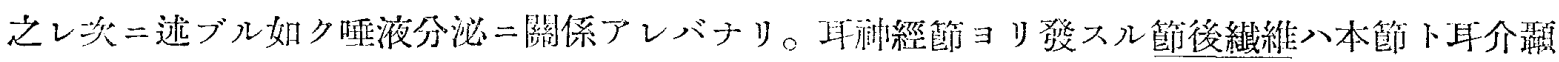

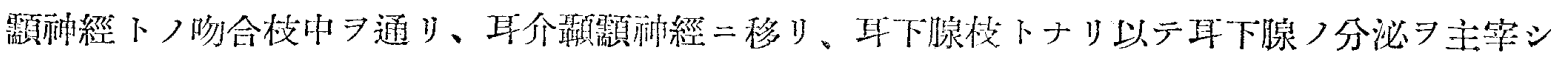
水分多キ唓液ヨ多量二分泌セシム。

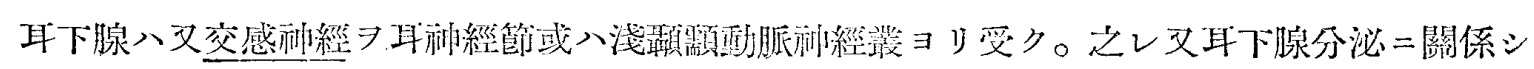
水分少キ濃厚ナルモノヨ少ク出サシム。

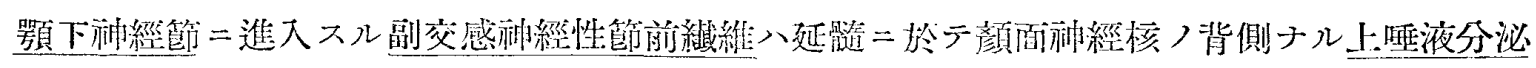

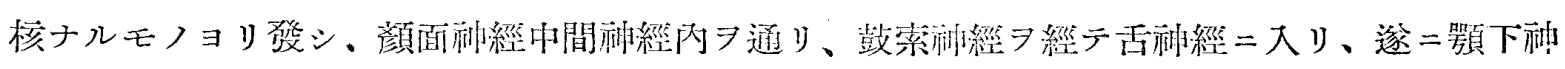

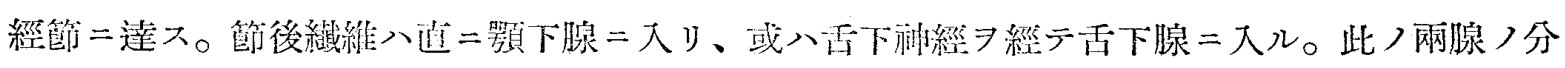

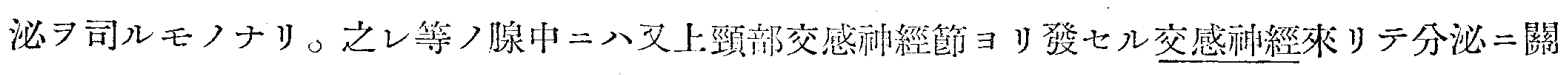
係ス 即于副交感性刺战ニテハ水分多手唾液 习少量二分泌大。

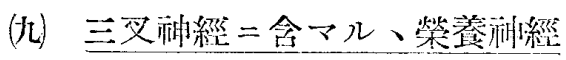

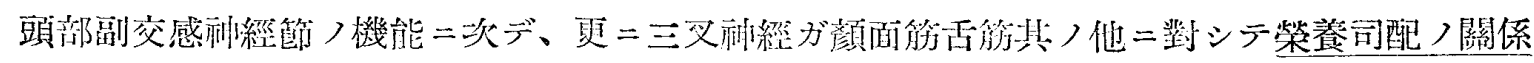
ヨ有スル事习知ラザルベカラズ。

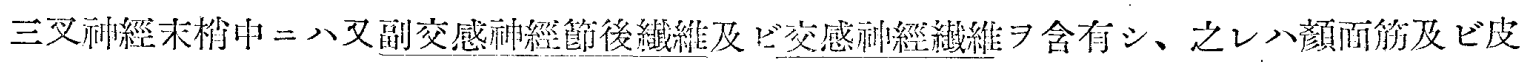

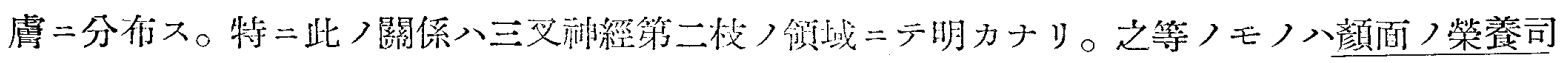
配ヨ行フモノニシテ、其ノ司配脫落スレバ、艾磨腺ノ分泌ヨ害シ、立毛筋ノ機能八冒サレ、皮

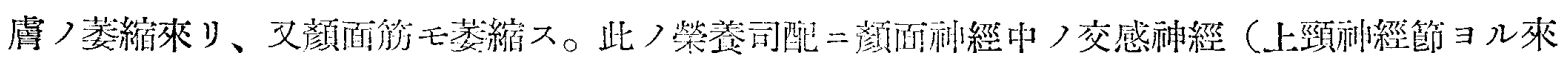

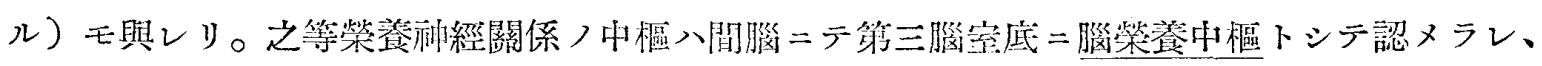
又脊髓榮餋中樞モ存ス卜唱へラル。

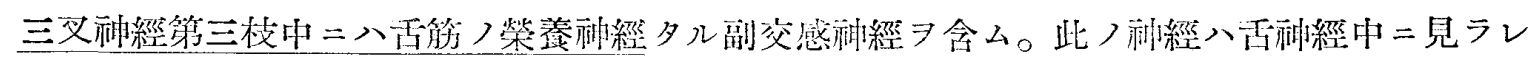

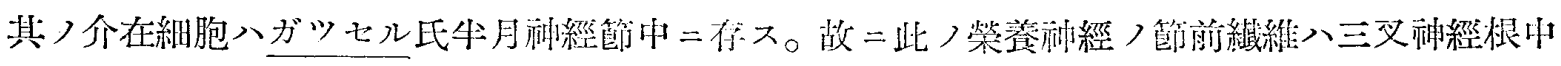
ニ見ラレ、古神經中ノモノ八節後㵶維ナリ。

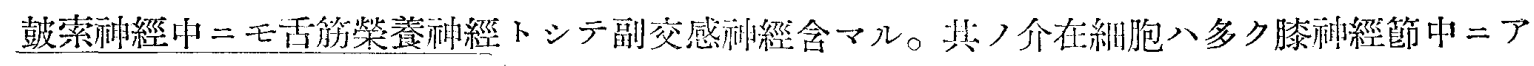

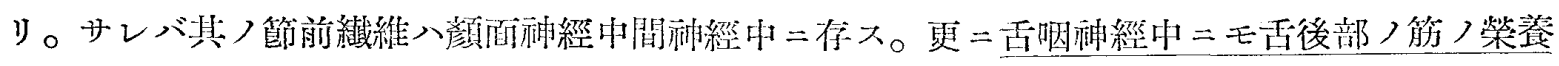
神經トシテノ副交感神經含マル。其ノ介在細胞八恐ラク岩樣神經節印ニ存セン。

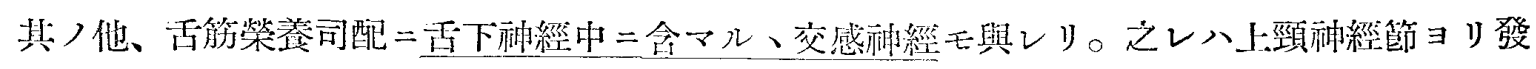
シ、血管: 二沿ヒテ來リ、舌下神經中ニ入レルモノテリ。

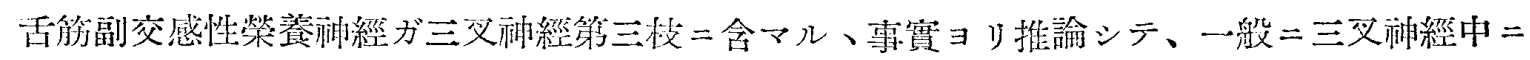

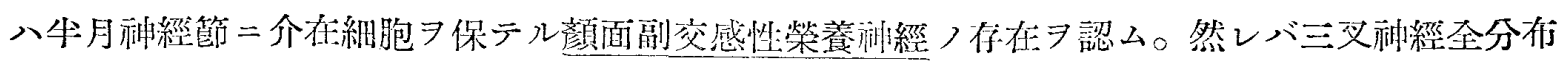

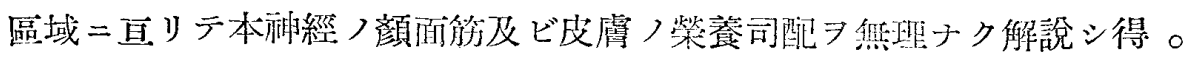

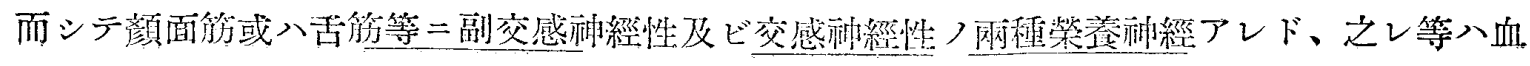


管司配ニ於ふル如ク拮抗作用ヨ示ス事ナク、却ツテ兩者相協調シテ作用スベシ。

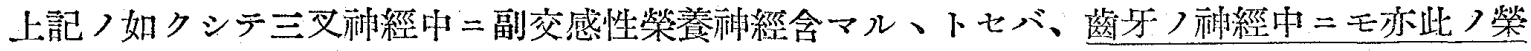

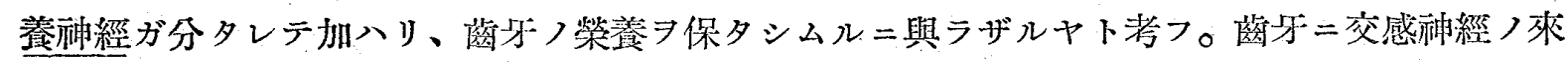

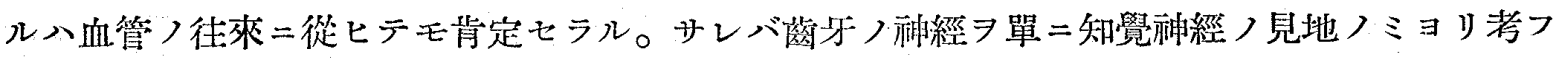
ルハ足ラザルモノトス。

\section{(十) 三叉神經八局所解剖的事項}

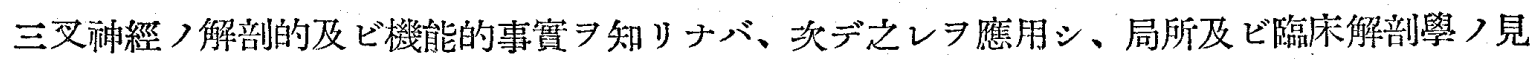
地ヨリ二、三述ブル所アルベシ。

三叉神經ノ枝八骨孔二出入スル事多キガ故二、生體=於テ此つ骨孔ノ位置ヨ標示シ得バ、其 ノ當該訮經ノ位置 都合ナラン。以下余ノ經驗ニテ知リ得シ結果ヨ述ブベシ。

上眼菓孔(截痕)八上眼巢緣內側生部

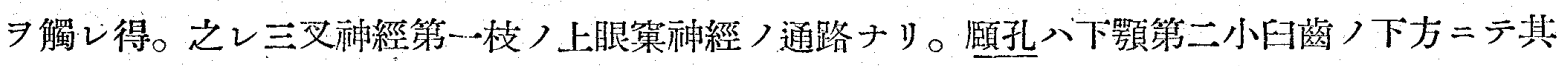
部下顎骨體入高サノ約二分，一以下ノ所二位ス。此ノ孔ハ正面二向ハズシテ後上外側方二向人

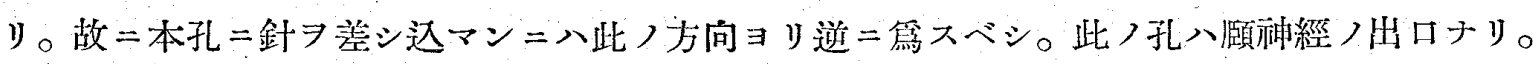

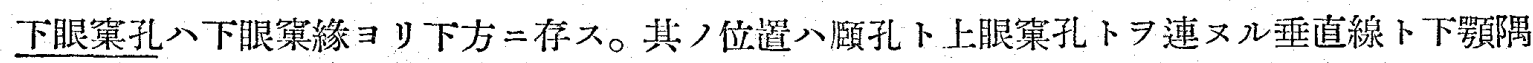
卜鼻根(前頭鼻骨縫合中點)トヨ結ブ科線卜ノ交叉點二賞ル。此)點

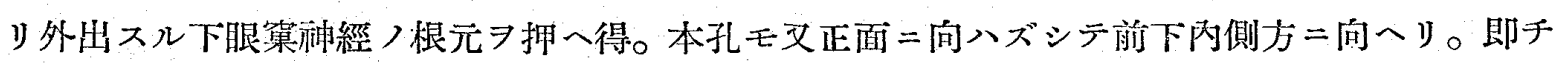

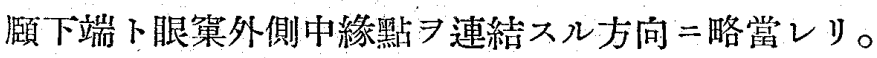

下齿槽神經ノ進入スル下顎孔分下顎枝內面二位シ、此八位置ヨ外表ヨリ指示スルハ難シ。此

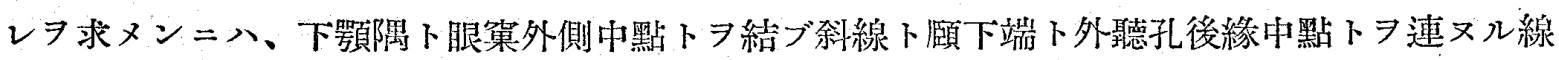
トノ交點入之レニ當レリ。即チ本交點シ指頭ニテ壓スレバ其ノ彼方二下顎孔ハ在ルベシ。

（十一）三父神經）臨床解剖的考察

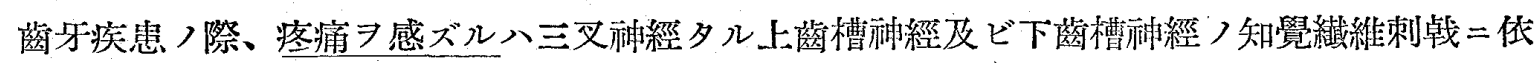

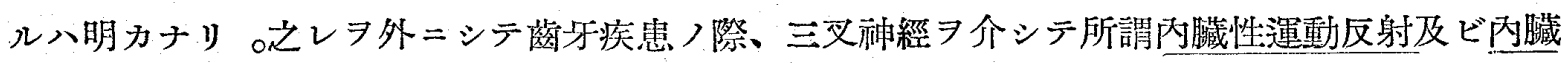
性知覺反射) 現象來ル。此ノ反射現像八理論的二充分可能ニシテ且ツ之レテ明カニ說明シ得ベ ク、又實際二モ良ク觀察セラル、モノナレド、臨床遥科醫ヨリ多ク顧慮セラレズ。以下二、三 ノ實例 語ラン。

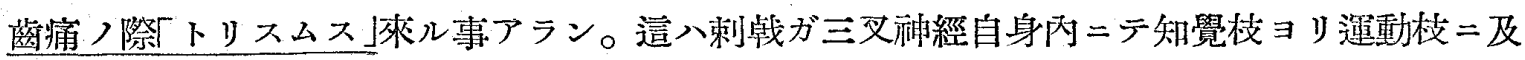

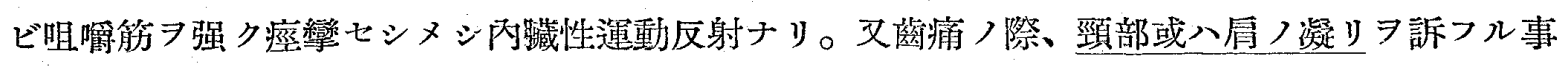

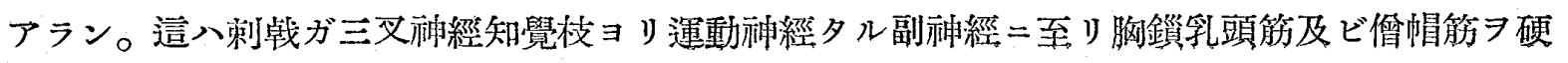
結セシメシ內臟性運動反射ナリ。 


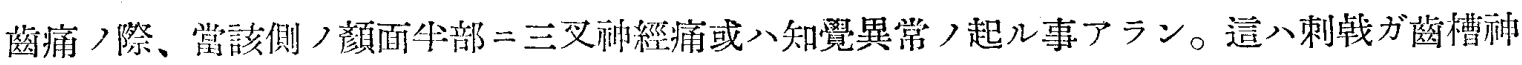

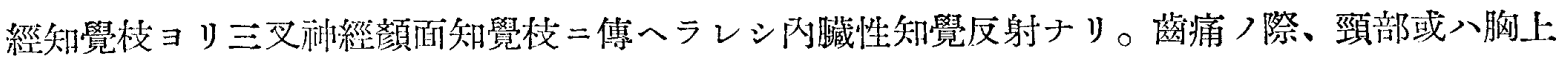

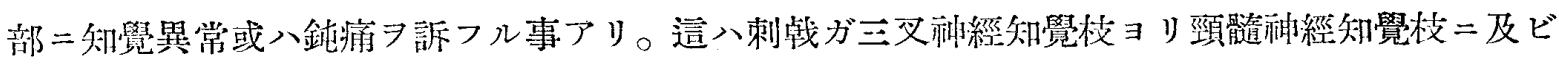
シ內臟性知覺反射ナリ。

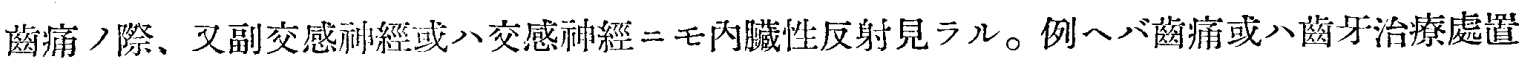

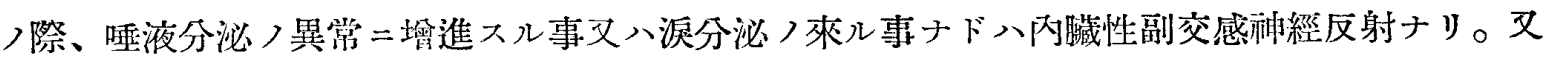
拢䔎〉際、何等恐ルベキ疼痛ナキニ係ラズ、顔面蒼白トナリ且”冷汗ヨ出スモノアリ。這八交 感神經及ビ副交感侪經兩者二現ハレシ反射ニシテ、荅白トナリシハ交感神經 ノ反射興舊二テ血

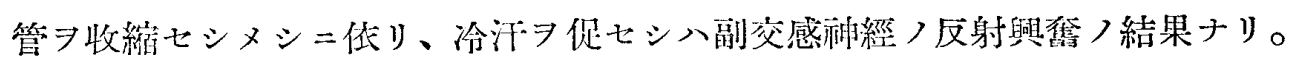

又顔面ノ牛側萎綰症ナルモノアリ。這八三叉神經痛或八其ノ他ノ三叉神經障害ノ際徍々見ラ ル、モノニシテ、顔面笳八多諭、皮膚腺、皮下脂肪組織マデ退行萎縮ス。三叉神經枝別中二八 副交感神經及ビ交感神經ガ榮養神經トシテ含マルレバ、何等カノ機會ニ於テ之レ等ノ害七ラル

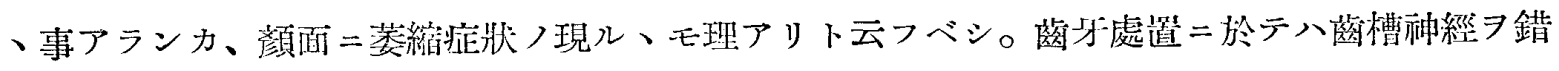

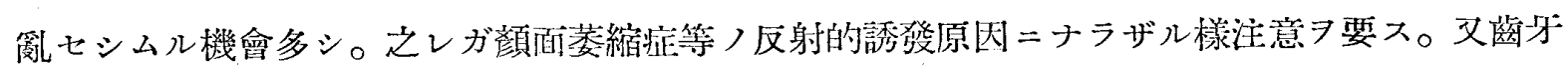
二外敬的二病變ナクシテ甚ダ弱キモノナキカ。這ハ三叉神經性榮養障害ノ紹果ナラザルカラ思 ハシム。

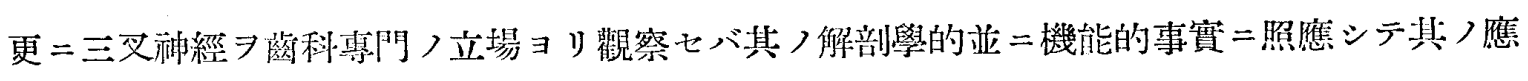

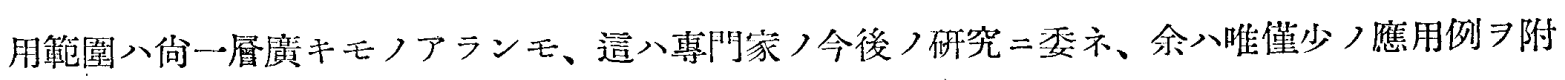
加提示ツテ理論的解說习試ミテ參考ニ倛シ、之レヨ以テ終リトセン。

最後二訬賢ノ御靜聽习深謝ス。

（昭和九年十月七日九州畨利㗨學會） 